Nippon Suisan Gakkaishi $\quad$ 72(2), 250-253 (2006)

\title{
特集＼cjkstart栽培漁業技術開発の最前線- I
}

\section{ブリの早期採卵技術とその効果}

\author{
浜田和久, $1 *$ 虫明敬 $\longrightarrow 2$ \\ 1独水産総合研究センター五島栽培漁業センター, 2 独水産総合研究センター栽培漁業部
}

Advanced spawning technique and its advantages in stock enhancement

and aquaculture of the yellowtail Seriola quinqueradiata

KAZUHISA HAMADA ${ }^{1 *}$ AND KEIICHI MUSHIAKE ${ }^{2}$

${ }^{1}$ Goto Station, National Center for Stock Enhancement, Fisheries Research Agency, Goto, Nagasaki 853-0508, ${ }^{2}$ Fisheries Stock Enhancement Department, Fisheries Research Agency, Yokohama, Kanagawa 220-6115, Japan

\section{1.はじめに}

ブリは, 日本列島近海を南北に移動する大型の回遊魚 で，定置網や巻き網等の漁業により年間約 5 万トン, 養殖においては年間約 15 万トンの生産量を誇るわが国 沿岸の水産資源の中でも最重要種の一つである。本種の 栽培漁業による資源増大を目的とした種苗生産技術の開 発は，1977 年から国の委託を受けて社日本栽培漁業協 会（日栽協）により天然親魚を用いた親魚養成と採卵に 関する技術開発が開始された。翌 1978 年には初めて日 栽協古満目事業場（現水産総合研究センター古満目栽培 漁業センター）で人工授精により受精卵が得られて以 来,1) 得られたふ化仔魚を用いた種苗生産試験が開始さ れ, 日栽協屋島事業場抢よび同五島事業場（現屋島栽培 漁業センターおよび同五島栽培漁業センター）では，そ れぞれ人工種苗を 100 万尾単位で生産することが可能 となった。その後は健全な種苗を生産するために形態異 常の防除等に関する技術の開発に取り組んでいる。2

\section{2. 養成したブリ親魚からの早期採卵}

天然親魚の産卵期は, 薩南海域で $2 \sim 3$ 月, 3) 四国と九 州沖合海域で 3 月から 4 月, ${ }^{4)}$ 抢よび能登半島近隣海域 では 6〜 7 月5)であるが, 主な産卵場は東シナ海といわ れている。一方, 天然成魚を海面小割生筫等で養成した 親魚（以下養成親魚と記す）では, 四国や九州の沿岸海 域における通常の産卵期は海水温が $19^{\circ} \mathrm{C}$ に達する 4 月 下旬から 5 月上旬で, 1,6) 薩南海域での天然魚の産卵期 よりも約 2 ヶ月遅い。この産卵期の違いに由来して, ブリの人工種苗は同じ時期の天然種苗に比べると著しく サイズが小さく, 人工種苗を放流した際の放流効果が上 がりにくい原因の一つと考えられてきた。7

このような理由から, 天然種苗のサイズに近づける, あるいは天然種苗よりも大きなサイズの人工種苗を生産 する技術の開発が強く望まれるようになった。一方, 本
種の養殖は, 1960 年頃から本格的な取り組みが始ま り, 西日本を中心に急速に発展してきた。しかし,これ までのブリ養殖に打ける種苗は, すべて天然稚魚（モジ ヤコ）に依存しており，この天然種苗も乱獲等による資 源量の減少が懸念されるため, 漁獲尾数には厳しい規制 が加えられている。また, 天然種苗の資源量には豊凶が あるため, 今後も養殖業発展のためにはいつまでも天然 種苗だけに依存できない状況にある。そのため, 近年, 養殖用種苗の計画的かつ安定的な確保とともに, 天然種 苗よりもサイズが大きいなどの付加価值を有する人工種 苗を生産するための技術開発への期待が高まっている。 天然種苗よりも大型サイズの人工種苗を確保するために は, 養成親魚の産卵時期を通常の産卵期 (4 月下旬から 5 月上旬）よりも早期化させる技術の開発が必要となっ た。

（1）２月における採卵技術の開発

古満目栽培漁業センターでは, 1991 年より日長と水 温の両条件を制御して養成親魚の卵黄形成を促進させ, HCG (human chorionic gonadotropin, 帝国臟器製薬) 注射を用いて産卵時期を早期化させる技術開発に取り組 んだ。その際の日長制御は, 30 日間の短日処理 (8L16D)，その直後から 30 日間をかけて明期が 18 時 間に達するまで次第に延長する長日化処理, そして, 30 日間の長日処理 $(18 \mathrm{~L} 6 \mathrm{D})$ を実施し計 90 日間行っ た。水温は, 海水の自然水温が $19^{\circ} \mathrm{C}$ を回った時点か ら加温により $19^{\circ} \mathrm{C}$ を維持した。その結果, 日長と水温 の両条件を制御することにより，1995 年には卵黄形成 を促進させることに成功するとともに, HCG 注射によ り通常の産卵期より 2 力月早く, 天然魚の産卵期と同 時期の 2 月に採卵（以下 2 月採卵と記す）させること に成功した。2）その後の研究によって, 短日処理抢よび 長日化処理を省略し 12 月から約 2 力月の長日処理と飼

* Tel : 81-959-88-2750. Fax : 81-959-88-2170. Email : kazhama@fra.affrc.go.jp 


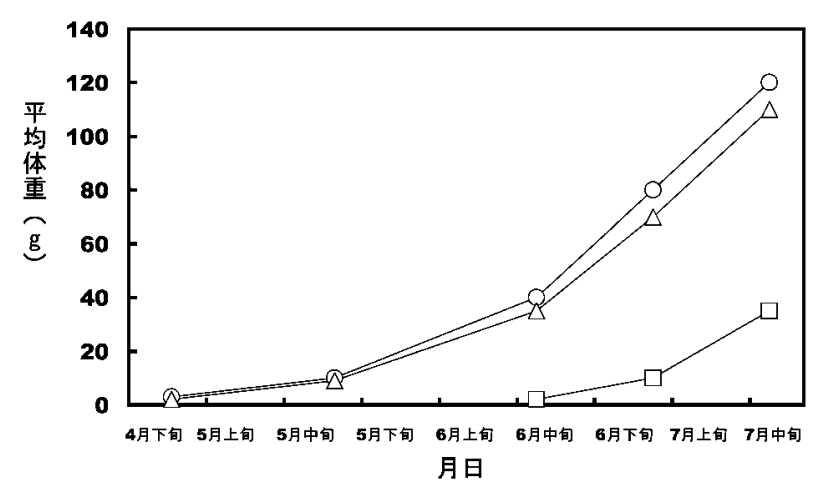

図 1 天然種苗と 2 月採卵由来の人工種苗の成長 $\circ$ 天然種苗, $\triangle 2$ 月採卵由来の種苗, 口4 月採卵由 来の種苗。

育水温の下限を $19^{\circ} \mathrm{C}$ に制御する手法により， 2 月に安 定的に採卵できる技術が開発された。9

2 月採卵由来の人工種苗は, サイズ, 成長抢よび生残 においては, 天然種苗と比較しても何ら遜色はなく, 有 意な差は認められなかった（図 1)。これら 2 月採卵由 来の人工種苗は, 成長および生残率の点で天然種苗と比 較しても遜色なく, 実際にこれらのブリ人工種苗は瀬戸 内海東部海域に放流された。その結果，同海域における ブリ当歳魚の全漁獲尾数の中で放流魚の占める混獲率 は, $20.7 \sim 34.7 \%$ に達し, 放流効果が実証されてい る。10,11)

(2) 12 月における採卵技術の開発

2000 年から養殖業振興支援, すなわち, 養殖用に適 した種苗の生産技術開発の取り組久が開始され，2002 年から五島栽培漁業センターではブリ人工種苗の付加価 值を高めるため, 天然種苗よりも大型の種苗をより早く 生産できるような卵の安定的かつ計画的な確保を目指し て, 天然魚の産卵期よりも約 2 力月早い 12 月に採卵 （以下 12 月採卵と記す）する技術の開発に着手した。 ここでは, 2002 年から 2004 年までの結果について述 ベる。

供試親魚は, 天然種苗を養殖業者が約 2 年間飼育し た $2^{+}$歳の成魚を海面小割生筫（円形, 直径 $8 \mathrm{~m} \times$ 水深 $5 \mathrm{~m})$ で約 9 力月から 2 年 7 力月養成した $3^{+}$歳から $5^{+}$ 歳魚である。親魚の平均尾叉長, 平均体重および肥満度 は，それぞれ 66〜 74 cm，5.5〜8.5 kg および 18〜21で あった。これらの親魚を毎年 9 月中旬にコンクリート 製陸上水槽（四角形, 実容量 $90 \mathrm{~kL}$ ) に収容し, 自然条 件下で 2 日間の水槽への馴致期間を設けた後に卵黄形 成の促進を図るため, 環境条件（日長および水温の両条 件）の制御を開始した（環境制御開始 0 日目とする）。 すなわち, 短日処理は明期 8 時間と暗期 16 時間 (8L16D) として 8：00から 16：00 までの8 時間は自 然日長条件下で飼育し, $16: 00$ から翌朝 $8: 00$ までは

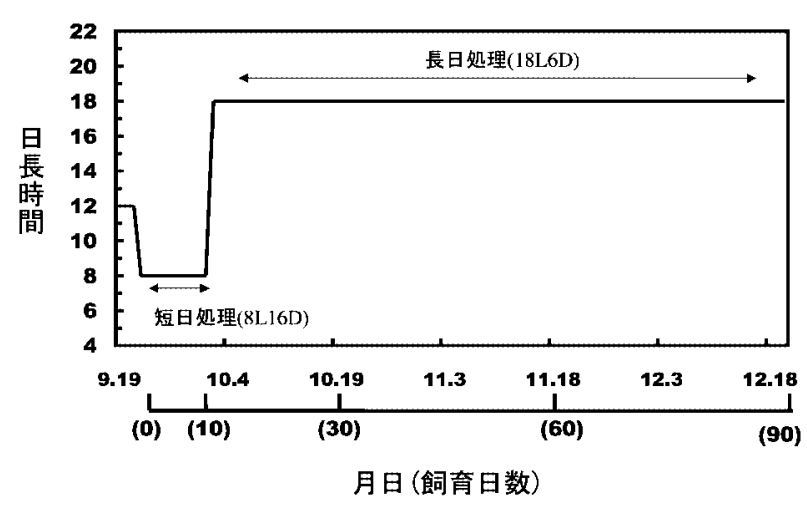

図 2 ブリの 12 月採卵における日長制御条件

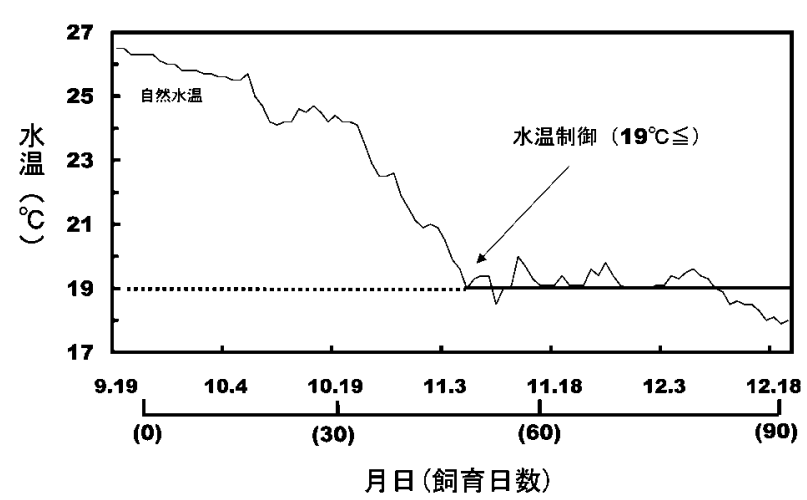

図 3 ブリの 12 月採卵に抢ける水温制御条件

水槽全体を遮光幕で覆い, その期間は, 10 日間とした (図 2)。長日処理は, 短日処理終了直後から明期 18 時 間と暗期 6 時間（18L6D）として 6：00から 24：00 ま での 18 時間について, タイマー制御により水槽直上部 に設置したレフランプ（500 W ） 2 灯を点灯 し，その期間は 80 日間とした（図 2)。水温条件は環境 制御開始 0 日目以降, 自然水温が $19^{\circ} \mathrm{C}$ を上回る場合に は自然条件とし, その後, 自然水温が $19^{\circ} \mathrm{C}$ を回るよ うになった時点から加温により最低水温を $19^{\circ} \mathrm{C}$ に維持 した（図 3)。陸上水槽に収容した直後から産卵が始ま る直前までの間, 市販配合飼料を給慨し, 環境制御開始 40 日目抒よび 90 日目にカニューレにより卵巣卵の一部 を採取して卵巣卵径を測定し, その平均值（以下平均卵 巣卵径）を親魚の成熟度の指標として調査を行った。そ の結果, 環境条件を制御して養成した親魚群の平均卵巣 卵径は, 両条件とも自然条件とした対照区と比較して, いずれの年も有意 $(t$ 検定, $P<0.01)$ に増大し, 卵黄 形成の促進が確認された（図 4)。環境制御開始 90 日目 には, すべての供試親魚に HCG 注射を行い, 水槽内に おける誘発産卵を試みた。HCG 注射を行った 2 日後に 産卵が認められ，2002 年には総採卵数で 999.8 万粒, 受精卵数で 418.9 万粒の大量採卵に成功し, 引き続き 


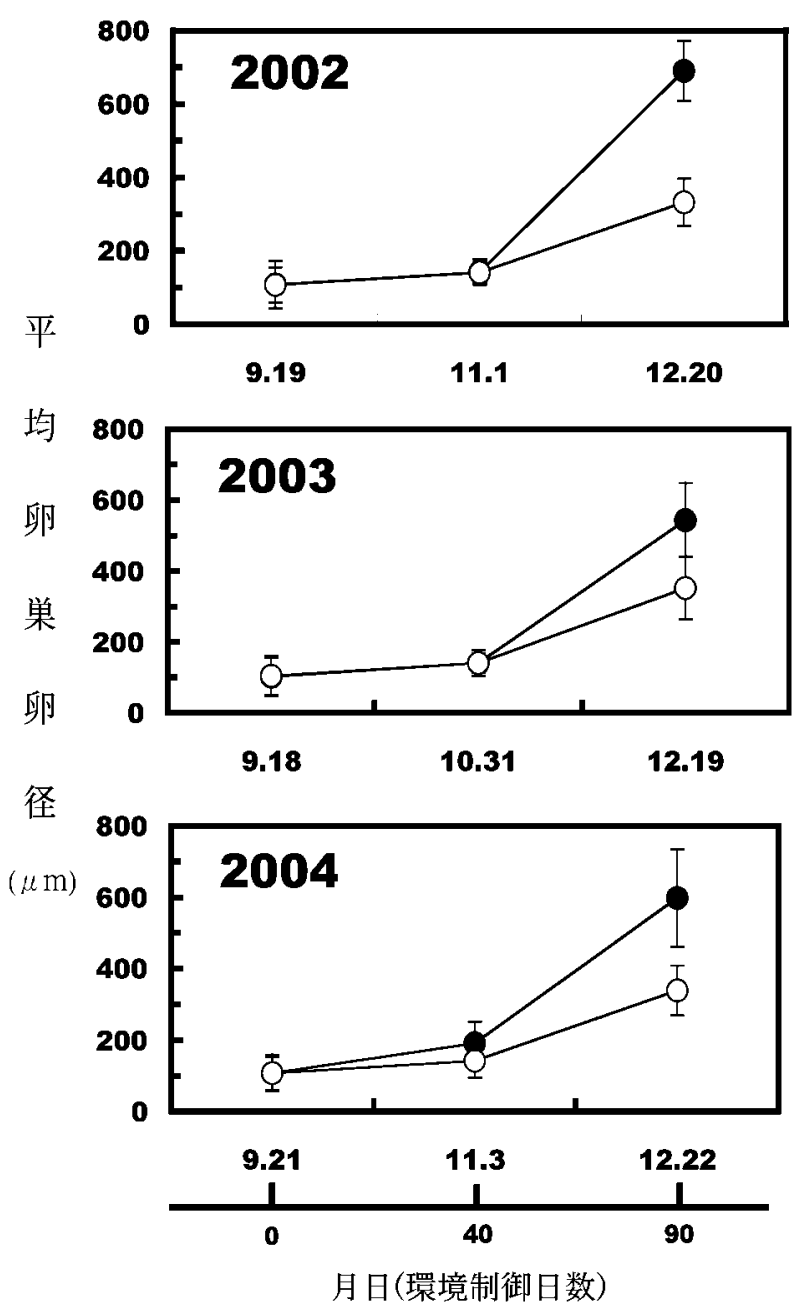

図 4 ブリの 12 月採卵における卵巣卵径の経時的変化 ○無制御区， - 環境制御区
2003 年と 2004 年にも採卵に成功した（表 1)。12）この 研究により，ブリ養成親魚の産卵期を通常の産卵期 (4 月下旬加 5 月上旬）加以約 4 力月, 天然親魚加ら は約 2 力月早める 12 月採卵に成功した。また, 各年の 初回産卵で得られたふ化仔魚を用いた初期飼育試験で は, 生残率が $14.1 \sim 36.7 \%$ となり, 通常のブリ種苗生 産に打ける初期生残率 $(10 \sim 15 \%)^{2)}$ と比較しても全く 遜色のない結果が得られた（表 2 ）。今後，12 月採卵に おいて雌親魚 1 尾当りの産卵数の増加および卵質等の 産卵成績の向上をもたらすような技術開発が必要であ る。

\section{3. 早期種苗の養殖へのメリットと今後の展望}

上述したように，ブリ養成親魚の産卵期を通常の産卵 期から約 4 力月早める 12 月採卵に成功した。得られた 卵を用いたこれまでの種苗生産試験では，3 月末に人工 種苗は全長 $14 \mathrm{~cm}$ （体重 $33 \mathrm{~g}$ ）に達することが判明し ている（浜田ら，未発表）。一方，天然種苗は 4 月末の 時点で全長約 $3 \mathrm{~cm}$ (体重 $3 \mathrm{~g}$ ) であり, 同じ時期の天然 種苗より有意に大きい人工種苗を養殖に利用すること で，養殖用種苗が安定的に確保できるとともに，一方で は天然稚魚を採捕する必要がなくなり，天然資源の保護 にも大きく貢献できるものと考えられる。この早期種苗 は, 翌年 12 月の満 1 歳の段階には出荷サイズの成魚 (2.5〜3 kg) まで成長することも予想される。このこと は, 出荷までに要する種苗の飼育日数が大きく短縮さ れ，養殖に関わる大幅なコストの軽減に貢献できること が期待される。また, 早期種苗の生産技術に QTL (quantitative trait locus) 解析に基づくマーカー選抜育 種や従来の選抜育種などの育種技術を導入することによ

表 1 五島栽培漁業センターにおけるブリ親魚の 12 月採卵試験における採卵結果

\begin{tabular}{|c|c|c|c|c|c|c|c|c|c|c|c|}
\hline \multirow[b]{2}{*}{ 年度 } & \multirow{2}{*}{ 試験区 } & \multirow{2}{*}{$\begin{array}{l}\text { 産卵月日 } \\
\text { (期間) }\end{array}$} & \multirow{2}{*}{ 総採卵数 } & \multirow{2}{*}{ 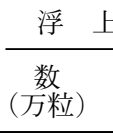 } & \multirow{2}{*}{$\frac{\text { 卵 }}{(\%)^{* 1}}$} & \multirow{2}{*}{$\begin{array}{l}\text { 受 精 } \\
\text { 数 } \\
\text { (万粒) }\end{array}$} & \multirow{2}{*}{$\frac{\text { 卵 }}{(\%)^{*}}$} & \multirow{2}{*}{$\begin{array}{c}\text { 受精卵径 } \\
(\mu \mathrm{m})\end{array}$} & \multirow{2}{*}{$\begin{array}{l}\text { 油球径 } \\
(\mu \mathrm{m})\end{array}$} & \multicolumn{2}{|c|}{ 交化仔魚 } \\
\hline & & & & & & & & & & (数 & $(\%)$ 率 \\
\hline \multirow[t]{2}{*}{2002} & 環境制御区 & $\begin{array}{c}2002.12 .22 \sim \\
2003.1 .5 \\
(15)\end{array}$ & 999.8 & 566.3 & 56.6 & 418.9 & 41.9 & $1180.7 \pm 59.7^{* 4}$ & $303.4 \pm 20.7^{* 5}$ & 183.8 & 18.4 \\
\hline & 無制御区 & - & 0 & - & - & - & - & - & - & - & - \\
\hline \multirow[t]{2}{*}{2003} & 環境制御区 & $\begin{array}{c}2003.12 .21 \sim \\
12.26 \\
(6)\end{array}$ & 86.9 & 44.0 & 50.7 & 32.8 & 37.7 & $1192.8 \pm 33.7$ & $305.5 \pm 12.8$ & 3.3 & 3.8 \\
\hline & 無制御区 & - & 0 & - & - & - & - & - & - & - & - \\
\hline \multirow[t]{2}{*}{2004} & 環境制御区 & $\begin{array}{c}2004.12 .24 \sim \\
2005.1 .2 \\
(10)\end{array}$ & 201.3 & 98.2 & 48.8 & 41.9 & 42.7 & $1174.2 \pm 29.9$ & $296.3 \pm 16.5$ & 23.7 & 11.8 \\
\hline & 無制御区 & - & 0 & - & - & - & - & - & - & - & - \\
\hline $\begin{array}{ll}* 1 & \text { 浮 } \\
* 2 & \text { 受 } \\
* 3 & \text { 子 } \\
* 4 & \text { 平 } \\
* 5 & \text { 平 }\end{array}$ & $\begin{array}{l}\text { 上卵率は総採卵 } \\
\text { 倩率は総採卵数 } \\
\text { 化率は総採卵数 } \\
\text { 清球径土標準 }\end{array}$ & $\begin{array}{l}\text { 数に対する浮上卵 } \\
\text { に対する受精卵数 } \\
\text { に対するふ化仔魚 } \\
\text { 準偏差を示す。 } \\
\text { 偏差を示す。 }\end{array}$ & $\begin{array}{l}\text { 数の割合で水 } \\
\text { の割合で女求女 } \\
\text { 数の割合で }\end{array}$ & $\begin{array}{l}\text { 奴た。 } \\
\text { た。 } \\
\text { めた。 }\end{array}$ & & & & & & & \\
\hline
\end{tabular}


表 2 ブリ親魚 12 月採卵試験より得られた仔魚の初期 10 日間の飼育結果

\begin{tabular}{|c|c|c|c|c|c|c|c|c|c|}
\hline \multirow{2}{*}{ 年度 } & \multicolumn{2}{|c|}{ 仔魚の活力 } & \multirow{2}{*}{$\begin{array}{c}\text { 飼育期間 } \\
\text { (日数) }\end{array}$} & \multirow{2}{*}{$\begin{array}{c}\text { 水槽の } \\
\text { 大きさ } \\
(\mathrm{kL})\end{array}$} & \multirow{2}{*}{$\begin{array}{c}\text { 飼育水温 } \\
\left({ }^{\circ} \mathrm{C}\right)\end{array}$} & \multirow{2}{*}{$\begin{array}{l}\text { 収容尾) } \\
\text { (数 }\end{array}$} & \multirow{2}{*}{$\begin{array}{c}\text { 子小化後10 目 } \\
\text { 9告残率 } \\
(\%)\end{array}$} & \multicolumn{2}{|c|}{ 全長（mm） } \\
\hline & $\mathrm{N}=$ & $\mathrm{SAI}^{* 1}$ & & & & & & 日齢 3 & 日齢 10 \\
\hline 2002 & 15 & 15.3 & $\begin{array}{l}2002.12 .25 \sim \\
2003.1 .4(10)\end{array}$ & 200 & $19.5 \sim 22.2$ & 2,000 & 14.1 & $3.6 \pm 0.1^{* 2}$ & $4.8 \pm 0.3^{* 2}$ \\
\hline 2003 & 4 & 19.2 & 飼育試験は未実施 & & & & & & \\
\hline 2004 & 9 & 19.8 & $\begin{array}{l}2004.12 .27 \sim \\
2005.1 .6(10)\end{array}$ & 200 & $19.4 \sim 22.2$ & 2,000 & 36.7 & $3.8 \pm 0.1$ & $4.8 \pm 0.3$ \\
\hline
\end{tabular}

*1 無給慨生残指数 (survival activity index)

*2 平均全長 \pm 標準偏差

り，耐病性，高成長あるいは味が良いなどの優良経済形 質を有する品種の作出にも強い期待が寄せられている。 さらに, 早期種苗への付加価值としてDHA（ドコサへ キサエン酸）などの高機能成分を付加させる技術の開発 も健康ブームの波に乗った消費者ニーズに合致している といえよう。

ブリで開発された早期採卵技術は，カンパチやヒラマ サ等のブリ属をはじめとした他の海産魚類においても十 分応用可能な技術となり得るものと考えられる。また， 本種の繁殖特性に応じた飼育環境をコントロールするこ とにより，成熟・産卵を効果的に制御する技術が開発さ れ，ひいては卵が必要な任意の時期に，いつでも産卵さ せることができる採卵技術の開発が期待される。

これまでに早期種苗の養殖への利用に関するメリット について述べたが，現段階では早期種苗が養殖用種苗と しての価值を十分に発揮できるとは言い難い。その一つ に，種苗の頭部と口部を中心とした形態異常の問題があ る。特に 12 月採卵由来の人工種苗の種苗生産では, 飼 育水槽からの取り揚げ時の形態異常の発現率は 24.6 ～ 41.7\% に及ぶとの報告がある。13) したがって，この形態 異常を防除可能な技術開発の成否は, 人工種苗を用いた ブリ養殖の将来を左右していると言っても過言ではな い。

\section{文献}

1）古満目親魚養成前進基地. 陸上水槽に抢けるブリの自然
産卵. 栽培技研 1978; 7 (2): 51-54.

2) 山崎英樹, 塩澤 聡, 藤本 宏. 日本栽培漁業協会に打 けるブリ種苗生産の現状. 水産増殖 2002; 50: 503-506.

3）松田星二. 南西海区水域に抢ける魚卵・稚魚の研究一 1 出現種類と出現期. 南西水研研報 1969; 2: 49-83.

4）楳田 晋. ブリ。「水産学シリーズ 海産魚の産卵・成熟 リズム」(廣瀬慶二編）恒星社厚生閣, 東京. 1991; 92100.

5）辻 俊宏. 能登半島沿岸で漁獲されるブリ成魚の成熟 度. 石川県水産総合センター, 石川. 2000; 2: 37-39.

6）日本栽培漁業協会. ブリの親魚養成技術開発. 栽培漁業 技術シリーズ 5, 日本栽培漁業協会, 東京. 1999; 1-72.

7）藤本 宏, 池脇義弘, 城 泰彦, 上田幸男, 天真正勝, 大梘觀三．徳島県鳴門海陕に放流したブリの天然 0 歳魚 と人工種苗 0 歳魚の特性について。栽培技研 1994; 23: 61-75.

8) Mushiake K, Kawano K, Kobayashi T, Yamasaki T. Advanced spawning in yellowtail, Seriola quinqueradiata, by manipulations of the photoperiod and water temperature. Fish. Sci. 1998; 64: 727-731.

9）今泉 均, 堀田卓朗, 河野一利, 山崎哲男. ブリの 2 月 採卵に拈ける日長制御方法の改良. 栽培技研 $2002 ; 30$ : $1-6$.

10）藤本 宏, 山崎英樹. 瀬戸内海東部海域におけるブリ早 期種苗の放流効果. 栽培技研 2001; 29: 21-34.

11）須田 明, 岩本明雄, 藤本 宏, 山崎英樹, 小畑泰弘. 瀬戸内海東部水域に放流されたブリ早期種苗群から期待 される生産効果の総合評価. 栽培資源調査検討資料 17 , 水産総合研究センター, 横浜. 2004: 1-59.

12）浜田和久, 虫明敬一. 日長および水温条件の制御による ブリの 12 月採卵. 日水誌 $2006 ; 72$ : 印刷中.

13）高橋 誠. 早期優良種苗の量産安定化技術開発（ブリ）. 平成 15 年度日本栽培漁業協会事業年報, 日本栽培漁業 協会, 東京. 2003; 130 . 